\title{
Invited Commentary: The Future of U.S. Natural Gas Is Utilities, Export, and Trucks, not Cars
}

\author{
John German
}

Published online: 6 February 2014

(C) Springer International Publishing AG 2014

For the last three or four years, natural gas prices, in dollars per unit of energy, have been roughly half that of petroleum. This is fueling efforts to replace petroleum use in transportation with natural gas, leading to multiple potential benefits for consumers, energy security, and the economy.

Light-duty vehicles (cars and light trucks) account for about two-thirds of transportation petroleum consumption and are a major focus of efforts to displace petroleum with natural gas. However, I am dubious that there will be significant use of natural gas in light-duty vehicles, at least in the USA, for a variety of reasons.

Historically, natural gas prices, per unit of energy, have tracked petroleum prices reasonably closely, as illustrated in Fig. 1. It is only the recent surge in natural gas fracking that has disrupted the historical relationship and made natural gas far cheaper. This is due to an imbalance between the supply of natural gas, which has increased quickly, and demand, which has taken longer to adjust.

How long will this price differential last? Unlike petroleum, which is a worldwide commodity, natural gas prices in the rest of the world are several times higher than they are in the USA. The USA has never imported or exported large quantities of natural gas, so there is a relatively small shipping network. This means that our excess natural gas cannot be exported in large quantities, depressing the domestic price. This depressed price is what is driving the search for ways to use natural gas, but it will also drive development of port liquefaction and shipping facilities to export the natural gas.

In addition, domestic use of natural gas for transportation purposes must compete with displacing coal to generate electricity. Natural gas has major advantages over coal in utility plants that go far beyond price. Natural gas is much cleaner

J. German $(\bowtie)$

Senior Fellow, International Council on Clean Transportation,

Washington, USA

e-mail: John@theicct.org and dramatically reduces sulfur and mercury emissions; it cuts global warming gases roughly in half, and allows utilities to rapidly ramp electricity generation up and down to match demand. Combined with the recent price drop for natural gas, it should be no surprise that recent conversions of utility plants from coal to natural gas have occurred at historically unprecedented rates. The utilities will be a tough competitor for cheap natural gas.

Assuming that there will continue to be enough cheap natural gas to supply the export market, utilities, and transportation, there are a lot of different ways to use natural gas for transportation. It can be used to directly fuel engines running on natural gas; go through a gas-to-liquid process to create drop-in gasoline and diesel substitutes; steam-reformed to create hydrogen for fuel cell vehicles; or burned in powerplants to generate electricity for battery-electric vehicles. While fuel cell and battery-electric vehicles will not be on the road in large quantities for decades, it is unclear whether it would be better to convert vehicles to run on natural gas or turn natural gas into fuels that existing vehicles could use.

Converting vehicles to run on natural gas is expensive. The primary problem is the need for a large, expensive fuel tank to hold compressed natural gas. Even when compressed the energy density of natural gas is much lower than that of gasoline, thus it requires a much larger tank to provide the same driving range. In addition, vehicle engines must be redesigned to use a gaseous fuel and they must be a bit larger to provide the same amount of power. The redesign costs are not large if natural gas vehicles are sold in large quantities, but they are substantial for low volume vehicles. For example, the Honda Civic natural gas vehicle retails for over US\$7,000 more than a comparable gasoline Civic, because it sells in low volumes. A recent study by the National Academy of Sciences on Transitions to Alternative Vehicles and Fuels found that the cost increment, before retail price markup, for 2030 high volume production of natural gas vehicles would be about US\$800 for cars and US\$1,000 for light trucks. In addition, 


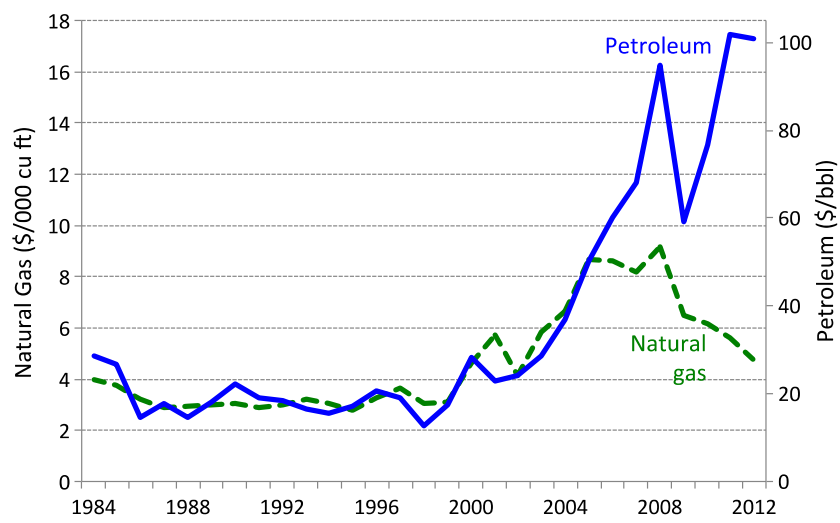

Fig. 1 Petroleum and Natural Gas Historical Price Comparison (historical dollars) Data from: U.S. Energy Information Administration Monthly Energy Review, October 2013 http://www.eia.gov/totalenergy/data/ monthly/\#prices

room must be found for the larger storage tank, reducing the interior space in the vehicle. Finally, a natural gas refueling infrastructure must be developed, or natural gas home refueling systems, which utilize the existing natural gas home utility infrastructure, must come down in price. These problems are solvable in the long run if natural gas prices remain low, but will derail attempts to convert to natural gas for lightduty vehicles if natural gas prices increase to levels comparable with petroleum.

Natural gas can also be made into liquid fuels. The simplest and cheapest way is to make it into ethanol. Unfortunately, ethanol is not a good fuel, primarily because it has one-third lower energy density than gasoline. This low energy density can be hidden in $10 \%$ ethanol blends with gasoline, but it becomes a major barrier in trying to market $85 \%$ ethanol blends (E85). The cost of E85 must be at least a third lower, per gallon, in order to compete with gasoline, especially when the $40 \%$ longer range with gasoline is considered. A better solution would be to turn natural gas into a drop-in fuel similar to existing fuels. Creating a diesel-like fuel would be especially advantageous, due to the worldwide shortage of diesel refinery capacity and the higher price for diesel. The first step is to make syngas, a gaseous mixture high in hydrogen and carbon, from natural gas. Next, the Fisher-Tropsch reaction can be used to create a hydrocarbon-based fuel that can be used as a drop-in diesel replacement. Another option is to create gaseous dimethyl ether (DME) from methanol produced from syngas. Although negligible changes are needed for a diesel engine to run on DME, it is not a drop-in replacement and a new fuel system would be required. These solutions have been demonstrated, but have yet to be proven economically viable on a large scale. Finally, any conversion of natural gas into a liquid fuel will be competitive only if natural gas prices remain significantly lower than petroleum.
If there is enough cheap natural gas to use for transportation, and the conversion of vehicles to run on natural gas makes economic sense, what is the highest value use within transportation? Natural gas can be used for light-duty, heavyduty, trains, and marine use. Heavy-duty vehicles, including buses, use a lot more fuel over their life and they have a lot more room for the natural gas tanks than light-duty vehicles. In addition, many urban trucks and buses are fueled at central locations, mitigating concerns about infrastructure. The same logic applies to trains. Thus, the economic case for converting heavy-duty vehicles and trains to natural gas is far more compelling than converting light-duty vehicles. This is also true if natural gas is converted into liquid fuels instead of being used directly, as the highest value fuel is a diesel replacement. In fact, bus, refuse, and delivery fleets are already switching to natural gas, on a more and more frequent basis.

Natural gas is often touted as a way to reduce greenhouse gases. This is true when compared with coal, which has twice the carbon emissions per unit of energy than petroleum. However, the $\mathrm{CO}_{2}$ emission from the tailpipe with natural gas is only about $24 \%$ lower than for gasoline or diesel, and natural gas (primarily methane) is a potent greenhouse gas. It only takes a percent or so of methane leakage in the entire chain, from wells to wheels, to offset the $\mathrm{CO}_{2}$ reductions compared with petroleum. In addition, the energy required to convert natural gas to ethanol or a drop-in diesel fuel is such that there will be no greenhouse gas emission saving from such technologies - and possibly an emissions increase. Thus, unless the methane leakage problem can be solved, global warming is not a reason to switch from petroleum to natural gas.

In conclusion, it is highly unlikely that natural gas will gain significant light-duty vehicle market share, beyond niche applications such as centrally-fueled fleets. Displacement of coal in utilities, export, and use in heavy-duty and trains are all much better high-value propositions for natural gas use. In addition, as utilities and heavy-duty increase their use of natural gas and more is exported, it is highly unlikely that natural gas will remain significantly cheaper than petroleum. Furthermore, large amounts of liquid hydrocarbons are also being extracted from the fracking process, which will tend to depress the price of domestic petroleum and narrow the price gap between natural gas and petroleum. Only if natural gas prices remain much lower than petroleum over time, despite higher demand and exports, will a significant market develop for light-duty vehicles.

\section{Compliance with Ethics Guidelines}

Conflict of Interest John German receives grants to his institution from ClimateWorks Foundation and Hewlett Foundation for vehicle and fuel work. 